\title{
Erratum to: Potential long-term storage of the predatory mite Phytoseiulus persimilis
}

\author{
Eric W. Riddick $\cdot$ Zhixin Wu
}

Published online: 24 August 2010

(C) International Organization for Biological Control (IOBC) 2010

\section{Erratum to: BioControl \\ DOI 10.1007/s10526-010-9297-7}

The Acknowledgments section was missing in the original publication. The missing section is shown below.

\section{Acknowledgments}

Juan A. Morales-Ramos and M. Guadalupe Rojas supplied Lima bean leaves infested with two-spotted spider mites. George Broufas, Thomas A. Coudron, and George D. Yocum provided helpful comments on an earlier version of this manuscript. The remarks of three anonymous reviewers were helpful. The United States Government has the right to retain a nonexclusive, royalty-free license in and to any copyright of this article. This article reports the results of research only. Mention of a commercial or proprietary product does not constitute an endorsement of the product by the United States Department of Agriculture.
The online version of the original article can be found under doi:10.1007/s10526-010-9297-7.

E. W. Riddick $(\bowtie) \cdot$ Z. Wu

National Biological Control Laboratory,

USDA-Agricultural Research Service,

Stoneville, MS 38776, USA

e-mail: eric.riddick@ars.usda.gov 